\title{
APPLICATION OF MERCURY ISOTOPES FOR TRACING TROPHIC TRANSFER AND INTERNAL DISTRIBUTION OF MERCURY IN MARINE FISH FEEDING EXPERIMENTS
}

\author{
Sae Yun Kwon, ${ }^{*} \dagger$ Joel D. Blum, $†$ Michelle A. Chirby, $†$ and Edward J. Chesney $\ddagger$ \\ $\dagger$ Department of Earth and Environmental Sciences, University of Michigan, Ann Arbor, Michigan, USA

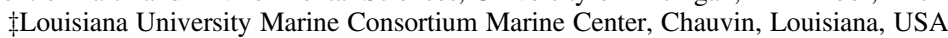

(Submitted 5 March 2013; Returned for Revision 14 April 2013; Accepted 11 June 2013)

\begin{abstract}
Feeding experiments were performed to investigate mercury $(\mathrm{Hg})$ isotope fractionation during trophic transfer and internal distribution of total $\mathrm{Hg}$ ( $\mathrm{THg}$ ) in marine fish on exposure to natural seafood. Young-of-the-year amberjack (Seriola dumerili) were fed with either blackfin tuna (Thunnus atlanticus; $2647 \mathrm{ng} / \mathrm{g} \mathrm{THg}$ ) or brown shrimp (Farfantepenaeus aztecus; $25.1 \mathrm{ng} / \mathrm{g} \mathrm{THg}$ ) for $80 \mathrm{~d}$ or $50 \mathrm{~d}$, respectively, and dissected for muscle, liver, kidney, brain, and blood. After $30 \mathrm{~d}$ of tuna consumption, $\mathrm{Hg}$ isotopes $\left(\delta^{202} \mathrm{Hg}\right.$ and $\left.\Delta^{199} \mathrm{Hg}\right)$ of the amberjack organs shifted to the tuna value $\left(\delta^{202} \mathrm{Hg}=0.55 \%, \Delta \Delta^{199} \mathrm{Hg}=1.54 \%\right.$, $)$, demonstrating the absence of $\mathrm{Hg}$ isotope fractionation. When amberjack were fed a shrimp diet, there was an initial mixing of the amberjack organs toward the shrimp value $\left(\delta^{202} \mathrm{Hg}=-0.48 \%\right.$ o, $\Delta^{199} \mathrm{Hg}=0.32 \%$ ) , followed by a cessation of further shifts in $\Delta^{199} \mathrm{Hg}$ and a small shift in $\delta^{202} \mathrm{Hg}$. The failure of $\Delta{ }^{199} \mathrm{Hg}$ to reach the shrimp value can be attributed to a reduction in $\mathrm{Hg}$ bioaccumulation from shrimp resulting from feeding inhibition and the $\delta^{202} \mathrm{Hg}$ shift can be attributed to a small internal fractionation during excretion. Given that the feeding rate and $\mathrm{Hg}$ concentration of the diet can influence internal $\mathrm{Hg}$ isotope distribution, these parameters must be considered in biosentinel fish studies. Environ Toxicol Chem 2013;32:2322-2330. (C) 2013 SETAC
\end{abstract}

Keywords: Methylmercury Internal distribution Trophic transfer $\quad$ Stable Hg isotope Fish

\section{INTRODUCTION}

Monomethylmercury (MMHg) in aquatic environments is a major health concern due to its persistence, bioaccumulation, and toxicity [1]. Fish consumption is the most important pathway for human exposure to $\mathrm{MMHg}$ [1], and it is estimated that more than $75 \%$ of the global fisheries product originates from marine environments [2]. Despite the health risks posed to humans consuming fish, many questions are still unanswered about the sources, bioaccumulation, and transport of $\mathrm{MMHg}$ to natural marine food webs as well as the internal processing of dietary $\mathrm{Hg}$ by marine organisms. Linking the bioaccumulated $\mathrm{Hg}$ in marine food webs to sources of $\mathrm{Hg}$ in the environment is a considerable challenge, in part due to the complex biogeochemistry of $\mathrm{Hg}$ in the ocean. Mercury isotopic analyses of fish tissues are increasingly being used to infer sources of $\mathrm{Hg}$ to aquatic food webs and to provide evidence of biogeochemical pathways of $\mathrm{Hg}$ in aquatic systems [3-6]. Lack of controlled experiments characterizing trophic transfer to marine food webs limits the interpretation of $\mathrm{Hg}$ isotopes in natural environments. In the present study, we performed feeding experiments to investigate $\mathrm{Hg}$ isotope fractionation during trophic transfer and internal distribution of total $\mathrm{Hg}(\mathrm{THg})$ in marine fish on exposure to diets composed of naturally accumulated $\mathrm{Hg}$ from 2 distinct marine environments (estuarine and offshore).

Stable $\mathrm{Hg}$ isotopes can vary in the environment as a result of fractionation during reactions and by mixing of isotopically distinct reservoirs. Mercury isotopes undergo 2 different types of fractionation. In mass-dependent fractionation, the degree of fractionation depends on the relative mass of the isotopes and is similar to other light-stable isotope systems (such as nitrogen

* Address correspondence to saeyunk@umich.edu

Published online 20 June 2013 in Wiley Online Library

(wileyonlinelibrary.com).

DOI: $10.1002 /$ etc. 2313 and carbon). Differences in mass-dependent fractionation are reported as $\delta^{202} \mathrm{Hg}$ in units of permil (\%o) [7]. Some of the environmental processes known to cause mass-dependent fractionation include biotic methylation [8], demethylation [9], and photochemical reactions [10]. Mass-independent fractionation is thought to occur via the magnetic isotope effect [11] and to a lesser extent the nuclear volume effect [12], primarily in odd-mass-number $\mathrm{Hg}$ isotopes. Mass-independent fractionation is the deviation in isotope ratios from the theoretical prediction for mass-dependent fractionation and is reported as $\Delta^{199} \mathrm{Hg}$ and $\Delta^{201} \mathrm{Hg}(\% \circ)$ [7]. Large-magnitude massindependent fractionation $(>0.5 \% 0)$ has been documented only during photochemical reduction and degradation of inorganic $\mathrm{Hg}(\mathrm{IHg})$ and $\mathrm{MMHg}[10,13]$. Because $\Delta^{199} \mathrm{Hg}$ and $\Delta^{201} \mathrm{Hg}$ have been shown to be directly proportional to the degree of photochemical demethylation, they have been used to estimate the extent of $\mathrm{MMHg}$ photodegradation in many natural ecosystems $[3-5,14]$. The ratio of $\Delta^{199} \mathrm{Hg} / \Delta^{201} \mathrm{Hg}$ can also be used to distinguish the degree of photochemical reduction and degradation of either $\mathrm{IHg}\left(\Delta^{199} \mathrm{Hg} / \Delta^{201} \mathrm{Hg}=1.00\right)$ or $\mathrm{MMHg}$ $\left(\Delta^{199} \mathrm{Hg} / \Delta^{201} \mathrm{Hg}=1.36\right)[10]$. Mass-independent fractionation of even-mass-number isotopes has also recently been reported in some atmospheric samples, but the mechanism producing this effect is not yet well understood $[15,16]$.

The fact that the odd-mass-number $\mathrm{Hg}$ isotopes fractionate primarily via photochemical reactions makes them very useful as a tracer for monitoring $\mathrm{MMHg}$ during trophic transfer and bioaccumulation. A recent experimental study documented an absence of $\delta^{202} \mathrm{Hg}$ and $\Delta^{199} \mathrm{Hg}$ fractionation of $\mathrm{MMHg}$ during trophic transfer to juvenile freshwater fish [17]. Other ecosystem-level studies have also shown similar $\Delta^{199} \mathrm{Hg}$ between closely linked prey and predators (e.g., pelagic sculpin and seal) and have suggested that $\Delta^{199} \mathrm{Hg}$ is unlikely to fractionate via internal metabolic processes [18]. Terrestrial plants such as lichens, rice, and aspen tree foliage have also 
demonstrated an absence of $\Delta^{199} \mathrm{Hg}$ fractionation during internal metabolic processes [19-21]. Aside from the potential utilization of $\Delta^{199} \mathrm{Hg}$ as a tracer, the influence of metabolic processes and the physiological state of fish on the fractionation of $\delta^{202} \mathrm{Hg}$ should be explored further.

In the present study, marine fish of the species Seriola dumerili (common name, greater amberjack; AJ) were exposed to diets of Thunnus atlanticus (common name, blackfin tuna) and Farfantepenaeus aztecus (common name, brown shrimp) in captivity. Amberjack are a marine reef-associated fish that are common in the northern Gulf of Mexico, USA. They are known for their rapid growth rate and adaptability in captivity. At an early life stage, they are often found in association with Sargassum patches, where they feed on shrimp, small crabs, and other small fishes. As they grow, they become aggressive predators and feed primarily on fishes (such as scad and blue runner) and invertebrates [22]. Due to the difference in their trophic levels and feeding habitats, the use of tuna and shrimp as food sources allowed us to compare the effects on AJ of consuming high- and low-Hg food sources from the Gulf of Mexico. We monitored the rate of isotopic adjustment of various organs in the $\mathrm{AJ}$ to a changing diet and determined whether isotopic fractionation occurred between organs as a result of internal metabolic processes.

\section{MATERIALS AND METHODS}

\section{Experimental design}

Young-of-the-year AJ were caught in surface waters using sabike rig fishing lures and were fished around Sargassum weedlines formed in offshore waters of the Gulf of Mexico, located approximately 20 miles north of the Brutus oil rig $\left(27^{\prime} 47.4286^{\prime \prime} \mathrm{N}, 90^{\prime} 38.5115^{\prime \prime} \mathrm{W}\right)$ and 165 miles southwest of New Orleans, Louisiana, USA. The juvenile AJ were reared in a recirculating seawater system at the Louisiana University Marine Consortium marine center (LUMCON) from June to August 2011. The tanks were maintained at temperatures of $22{ }^{\circ} \mathrm{C}$ to $30{ }^{\circ} \mathrm{C}$, pH 8.0 to 8.8 , and salinity 23 to $30 \mathrm{ng} / \mathrm{L}$ throughout the experimental period. AJ were divided into 2 treatment tanks, each containing 25 individuals, and fed with either blackfin tuna (hereafter referred to as tuna) or brown shrimp (hereafter referred to as shrimp) to apparent satiation for a total of a 50- or 80-d period, respectively. The tuna were also caught near the Brutus oil platform but at much greater depths ( $\sim 1000 \mathrm{~m})$ compared with AJ. The shrimp were caught in the bayous of Terrebonne Parish, Louisiana, USA $\left(29^{\prime} 22.9968^{\prime \prime} \mathrm{N}\right.$, $\left.90^{\prime} 75.3281^{\prime \prime} \mathrm{W}\right)$, located 2 miles to the west of LUMCON. The tuna and shrimp diets were prepared by removing the skin and exoskeleton, respectively, and cutting only the muscle tissues into small pieces, freezing them for later use.
Three to $5 \mathrm{AJ}$ were sacrificed at different time periods during the course of the feeding experiment (Table 1). On the day when AJ were first caught (referred to as day 0), 5 fish were randomly selected as a wild control. Three to $5 \mathrm{AJ}$ were sacrificed each at days 10,30, and 50 after consuming the tuna diet (referred to as $\mathrm{AJ}[\mathrm{T}])$. Amberjack that were fed with the shrimp diet (referred to as $\mathrm{AJ}[\mathrm{S}])$ were sacrificed at days $10,30,50$, and 80 .

Fish were measured for total length and wet weight prior to dissection and the extraction of muscle, liver, brain, kidney and blood at each time point. The dissection was performed by anesthetizing the fish with $1.5 \mathrm{~mL}$ of a clove oil solution $(10: 1$ ethanol to clove oil) diluted in 1 gallon of seawater. The caudal fin was removed to drain the blood into acid-washed glass vials. Muscle, liver, brain, and kidney were dissected using a stainless steel scalpel and scissors. For convenience, all components dissected in the present study (muscle, liver, brain, kidney, and blood) are referred to as "organs." All tools were thoroughly wiped with a paper wipe and cleaned with distilled water and alcohol between samples to avoid contamination. Each organ was placed in a preweighed plastic bag or acid-washed glass vial to obtain wet weights. The organs were then frozen at $-20{ }^{\circ} \mathrm{C}$, freeze-dried and further homogenized with mortar and pestle for $\mathrm{Hg}$ concentration and stable $\mathrm{Hg}$ isotope analyses at the University of Michigan. All $\mathrm{THg}$ concentrations are reported based on dry weight except for blood.

\section{Total Hg concentration analysis}

Organs from individual fish generally did not contain enough $\mathrm{Hg}$ for isotopic analysis, so composite samples were made from the organs of the 3 to 5 individuals sacrificed at each time point For muscle samples, both individual and composite samples were analyzed because there was enough $\mathrm{Hg}$ in muscle to analyze individual fish. The total $\mathrm{Hg}$ ( $\mathrm{THg}$ ) concentrations were determined by atomic absorption spectroscopy (AAS) after combustion at $800{ }^{\circ} \mathrm{C}$ using a Nippon Instruments MA-2000 Hg analyzer. Standard solutions of National Institute of Standards and Technology standard reference material (NIST SRM) 3133 were used to obtain calibration curves and for quality assurance and quality control. The values of replicate analyses were always within 5\%. Three standard reference materials-ERM CE 464 (average measured $\mathrm{THg}=4232 \mu \mathrm{g} / \mathrm{g}, n=8$ ), National Research Council Canada (NRCC) DOLT-2 (2193 $\mu \mathrm{g} / \mathrm{g}, n=3)$, and NRCC DORM-3 (362 $\mu \mathrm{g} / \mathrm{g}, n=8)$-were also analyzed, along with the samples and agreed within $10 \%$ of certified values.

\section{Methylmercury analysis}

Methylmercury concentrations were analyzed for the shrimp and tuna diet, as well as for the muscle, liver, kidney, and brain of $\mathrm{AJ}(\mathrm{S})$ at days 0 and 80 either at Wright State University, Dayton,

Table 1. Average organ mass, total body mass, and total fork length of amberjack fed shrimp (AJ[S]) or tuna (AJ[T]) at different time points

\begin{tabular}{|c|c|c|c|c|c|c|c|c|}
\hline & \multirow{2}{*}{$\begin{array}{l}\text { Day } 0 \\
(n=5)\end{array}$} & \multicolumn{2}{|c|}{ Day 10} & \multicolumn{2}{|c|}{ Day 30} & \multicolumn{2}{|c|}{ Day 50} & \multirow{2}{*}{$\frac{\text { Day } 80}{\operatorname{AJ}(S)(n=5)}$} \\
\hline & & $\mathrm{AJ}(\mathrm{S})(n=5)$ & $\mathrm{AJ}(\mathrm{T})(n=5)$ & $\mathrm{AJ}(\mathrm{S})(n=5)$ & $\mathrm{AJ}(\mathrm{T})(n=5)$ & $\mathrm{AJ}(\mathrm{S})(n=3)$ & $\mathrm{AJ}(\mathrm{T})(n=3)$ & \\
\hline Liver (g, wet wt) & $0.80 \pm 0.32$ & $0.95 \pm 0.41$ & $1.5 \pm 0.25$ & $2.3 \pm 1.4$ & $3.9 \pm 2.1$ & $2.2 \pm 1.2$ & $12 \pm 2.8$ & $2.0 \pm 1.9$ \\
\hline Kidney (g, wet wt) & $0.22 \pm 0.12$ & $0.20 \pm 0.07$ & $0.35 \pm 0.16$ & $0.65 \pm 0.27$ & $0.30 \pm 0.06$ & $0.44 \pm 0.15$ & $0.78 \pm 0.15$ & $0.78 \pm 0.75$ \\
\hline Brain (g, wet wt) & $0.43 \pm 0.13$ & $0.32 \pm 0.20$ & $0.44 \pm 0.12$ & $0.42 \pm 0.11$ & $0.40 \pm 0.12$ & $0.48 \pm 0.11$ & $0.56 \pm 0.17$ & $0.47 \pm 0.39$ \\
\hline Blood $(g$, wet wt $)$ & $2.9 \pm 1.4$ & $3.3 \pm 1.0$ & $4.3 \pm 0.92$ & $3.7 \pm 2.09$ & $3.5 \pm 0.51$ & $2.1 \pm 0.91$ & $3.2 \pm 1.3$ & $2.1 \pm 1.7$ \\
\hline Total mass (g, wet wt) & $162 \pm 72$ & $165 \pm 60$ & $229 \pm 59$ & $223 \pm 71$ & $197 \pm 29$ & $292 \pm 88$ & $377 \pm 66$ & $337 \pm 111$ \\
\hline Fork length $(\mathrm{mm})$ & $22 \pm 3.3$ & $21 \pm 2.7$ & $24 \pm 2.8$ & $23 \pm 2.0$ & $22 \pm 2.4$ & $30 \pm 2.7$ & $30 \pm 1.7$ & $27 \pm 2.7$ \\
\hline
\end{tabular}


Ohio, USA, or at the Metropolitan Council Environmental Services, St. Paul, Minnesota, USA, using an aqueous distillation method [23]. Briefly, the samples were digested with 4.6 M nitric acid at $60{ }^{\circ} \mathrm{C}$ for $12 \mathrm{~h}$ and distilled at $140{ }^{\circ} \mathrm{C}$ in Teflon distillation vessels. Distillates were added to $4.5 \mathrm{M}$ potassium hydroxide and sodium tetraethylborate for aqueousphase derivitization and collection of $\mathrm{Hg}$ on Tenax traps. After the separation of $\mathrm{Hg}$ species using a gas chromatography column, MMHg and $\mathrm{IHg}$ were converted to $\mathrm{Hg}^{\mathrm{O}}$ and analyzed via cold-vapor atomic fluorescence spectroscopy. Reagent blanks and standard reference material NRCC TORT-2 were included between samples for quality assurance. The reagent blanks showed no detectable $\mathrm{MMHg}$, and the recoveries of TORT-2 ranged between $91 \%$ and $107 \% \quad(n=8)$. The proportion of $\mathrm{THg}$ that occurs as $\mathrm{MMHg}$ is reported as $\% \mathrm{MMHg}$.

\section{Mercury isotope analysis}

Samples were weighed and loaded into ceramic boats with alternating layers of sodium carbonate and aluminum oxide powders that were baked in a muffle furnace at $750{ }^{\circ} \mathrm{C}$ overnight before use to ensure low-Hg blanks. The powders stabilize the combustion products and ensure retention in the first stage of the furnace. The ceramic boats were loaded into an offline 2-stage combustion furnace system. In the first combustion compartment, the samples were heated to $750{ }^{\circ} \mathrm{C}$ over a 6-h period to release all $\mathrm{Hg}\left(\right.$ as $\left.\mathrm{Hg}^{0}\right)$. Mercury-free oxygen was used to transport $\mathrm{Hg}^{0}$ to the second combustion compartment, maintained at $1000{ }^{\circ} \mathrm{C}$, and subsequently to an oxidizing "trap solution" of $1 \% \mathrm{KMnO}_{4}$ in $10 \%$ trace metal-grade $\mathrm{H}_{2} \mathrm{SO}_{4}$, which had been purged with $\mathrm{Hg}$-free argon gas for $4 \mathrm{~h}$ before use. To remove potential matrix components from samples, the trap solutions containing the oxidized $\mathrm{Hg}^{2+}$ were neutralized using hydroxylamine, reduced back to $\mathrm{Hg}^{0}$ by addition of $\mathrm{SnCl}_{2}$, and purged into another trap solution.

The procedural blanks were prepared by combusting only the combustion powders (without the sample) in a ceramic boat, transferring to a clean trap solution, and measuring for $\mathrm{THg}$ before and after the transfer steps. The blanks had an average of $0.3 \pm 0.1 \mathrm{ng} \mathrm{THg}(n=6)$. Measuring the THg concentrations of the trap solutions after both the combustion and the transfer steps also allowed monitoring of the recoveries of $\mathrm{THg}$ during the combustion and transfer processes. The standard reference materials ERM CE $464(n=5)$ and NRCC DOLT-2 $(n=3)$ were also combusted and transferred in the same manner as the samples to monitor the recoveries of $\mathrm{THg}$. The recoveries of the combustion and transfer steps of the samples and standard reference materials ranged between $97 \%$ and $106 \%$ and between $96 \%$ and $106 \%$, respectively.

A Nu Instruments multicollector inductively coupled plasma mass spectrometer (MC-ICP-MS) was used to measure $\mathrm{Hg}$ isotope ratios at the University of Michigan, Ann Arbor, Michigan, USA. The trap solutions were neutralized using hydroxylamine and diluted to between $1 \mathrm{ng} / \mathrm{g}$ and $5 \mathrm{ng} / \mathrm{g}$, using the same neutralized trap solution matrix, to match the $\mathrm{THg}$ concentration of the sample to the standards. Mercury was introduced to the MC-ICP-MS as $\mathrm{Hg}^{0}$ by reducing $\mathrm{Hg}^{2+}$ to $\mathrm{Hg}^{0}$ with $\mathrm{SnCl}_{2}$ and separating $\mathrm{Hg}^{0}$ from solution using a frosted glass tip phase separator. On-peak zero corrections were applied. Instrumental mass bias was corrected using an internal thallium (Tl) standard (NIST SRM 997) and by bracketing each sample with NIST SRM 3133 matched to sample THg concentrations and matrix composition. Mass-dependent fractionation is reported as $\delta^{202} \mathrm{Hg}$ in permil (\%o) referenced to NIST SRM 3133

$$
\begin{aligned}
\delta^{202} \mathrm{Hg}= & \left\{\left[\left({ }^{202} \mathrm{Hg} /{ }^{198} \mathrm{Hg}\right)_{\text {sample }} /\left({ }^{202} \mathrm{Hg} /{ }^{198} \mathrm{Hg}\right)_{\text {NIST3133 }}\right]-1\right\} \\
& \times 1000
\end{aligned}
$$

Mass-independent fractionation represents the difference between the measured $\delta^{x x} \mathrm{Hg}$ value and the value predicted based on mass-dependent fractionation and the $\delta^{202} \mathrm{Hg}$ value. Mass-independent fractionation is reported as $\Delta^{199} \mathrm{Hg}$ and $\Delta^{201} \mathrm{Hg}$ in permil (\%o). The calculation is based on an approximation valid for $\delta<10 \%$ [7]

$$
\begin{aligned}
& \Delta^{199} \mathrm{Hg}=\delta^{199} \mathrm{Hg}-\left(\delta^{202} \mathrm{Hg} \times 0.252\right) \\
& \Delta^{201} \mathrm{Hg}=\delta^{201} \mathrm{Hg}-\left(\delta^{202} \mathrm{Hg} \times 0.752\right)
\end{aligned}
$$

Analytical uncertainty at 2 standard deviations (SD) was estimated based either on replicate analysis of a standard solution (UM-Almáden) or on replicate analyses of procedural standards. In the present study, we used ERM CE 464 to report analytical uncertainty because it had a larger uncertainty. The standard solution UM-Almáden $(n=40)$ had mean values $( \pm 2 \mathrm{SD})$ of $\delta^{202} \mathrm{Hg}=-0.57 \pm 0.10 \%, \Delta^{201} \mathrm{Hg}=-0.03$ $\pm 0.06 \%$ o, and $\Delta^{199} \mathrm{Hg}=-0.02 \pm 0.06 \%$; standard reference material ERM CE $464(n=5)$ had mean values of $\delta^{202} \mathrm{Hg}=$ $0.65 \pm 0.10 \%$ o, $\Delta^{201} \mathrm{Hg}=1.93 \pm 0.08 \%$, and $\Delta^{199} \mathrm{Hg}=2.34 \pm$ $0.10 \%$; and DOLT-2 $(n=3)$ had mean values of $\delta^{202} \mathrm{Hg}=$ $-0.52 \pm 0.04 \%$ o, $\Delta^{201} \mathrm{Hg}=0.59 \pm 0.06 \%$, and $\Delta^{199} \mathrm{Hg}=$ $0.70 \pm 0.08 \%$.

\section{RESULTS}

Both $\mathrm{AJ}(\mathrm{T})$ and $\mathrm{AJ}(\mathrm{S})$ demonstrated considerable variation in total body mass and fork length within each time period (Table 1). The total body mass and the fork length of AJ at day 0 varied by 2.6- and 1.4-fold, respectively, and the variation persisted to a similar extent over the course of the experiment. The experiment was not designed to monitor the changes in body mass and length over time. Instead, AJ with a variety of sizes were selected randomly for the determination of the internal $\mathrm{Hg}$ isotope distribution. Although the variability is too large to accurately estimate the growth rate, the fact that the composite and individual samples show similar $\mathrm{THg}$ concentrations and $\mathrm{Hg}$ isotope behaviors suggests that fish size does not significantly affect the internal distribution of $\mathrm{Hg}$ isotopes (see results in Tuna treatment and Shrimp treatment).

\section{THg concentrations in amberjack}

The average THg concentrations in the tuna and shrimp diets were $2647 \pm 66 \mathrm{ng} / \mathrm{g}(n=3 ; 1 \mathrm{SD})$ and $25.1 \pm 3.3 \mathrm{ng} / \mathrm{g}$ ( $n=3 ; 1 \mathrm{SD}$ ), respectively, similar to values reported in other studies from the Gulf of Mexico [5,24]. Prior to the consumption of these diets (day 0), the AJ muscle, liver, kidney, brain, and blood had THg concentrations of $75.1 \mathrm{ng} / \mathrm{g}, 44.7 \mathrm{ng} / \mathrm{g}, 49.9 \mathrm{ng} / \mathrm{g}$, $12.0 \mathrm{ng} / \mathrm{g}$, and $1.70 \mathrm{ng} / \mathrm{g}$, respectively. The individual sample of AJ muscle had $\mathrm{THg}$ concentration of $75.3 \mathrm{ng} / \mathrm{g}$, which was similar to the composite sample. With consumption of either the tuna or the shrimp diets in captivity, the $\mathrm{THg}$ concentration of $\mathrm{AJ}(\mathrm{T})$ and $\mathrm{AJ}(\mathrm{S})$ organs increased rapidly with time (Figure 1). To assess the extent of $\mathrm{Hg}$ bioaccumulation in each organ of $\mathrm{AJ}(\mathrm{T})$ and $\mathrm{AJ}(\mathrm{S})$ at different times, we calculated the bioaccumulation factor (BAF; the ratio of $\mathrm{THg}$ concentration in each organ to the $\mathrm{THg}$ concentration in the diet, tuna or shrimp; Table 2). The AJ(T) and $\mathrm{AJ}(\mathrm{S})$ muscle demonstrated the highest BAF at day 10. After day 10, the highest BAF was 

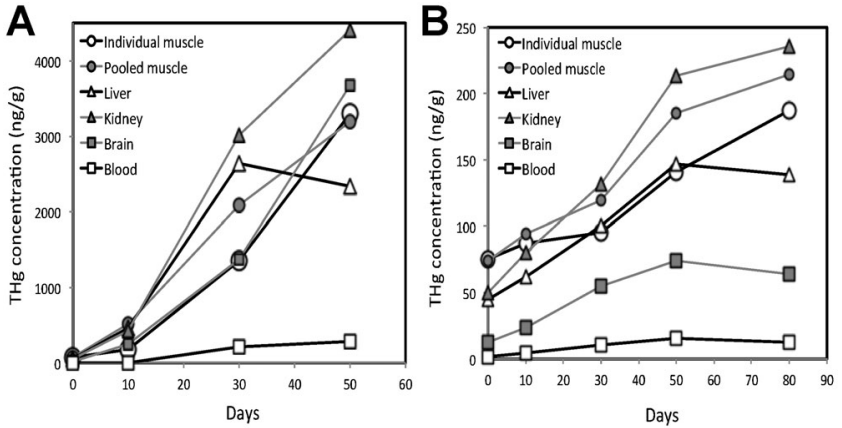

Figure 1. Total $\mathrm{Hg}(\mathrm{THg})$ concentrations (ng/g, dry wt) of the organs of amberjack fed a tuna diet (A) and amberjack fed a shrimp diet (B) at different time periods. The $\mathrm{THg}$ concentrations of the blood are reported in wet weight.

observed in the kidney and the lowest BAF in the blood of $\mathrm{AJ}(\mathrm{T})$ and $\mathrm{AJ}(\mathrm{S})$. At the end of the experimental period (days 50 and 80, for $\mathrm{AJ}(\mathrm{T})$ and $\mathrm{AJ}(\mathrm{S})$, respectively), the $\mathrm{THg}$ concentrations in $\mathrm{AJ}(\mathrm{T})$ were ranked by decreasing order: kidney $(4400 \mathrm{ng} / \mathrm{g})>$ brain $(3682 \mathrm{ng} / \mathrm{g})>$ muscle $(3201 \mathrm{ng} / \mathrm{g}$ composite, $3299 \mathrm{ng} / \mathrm{g}$ individual) $>$ liver $(2331 \mathrm{ng} / \mathrm{g})>$ blood $(277 \mathrm{ng} / \mathrm{g})$; and $\mathrm{THg}$ concentrations in $\mathrm{AJ}(\mathrm{S})$ were ranked by decreasing order: kidney $(235 \mathrm{ng} / \mathrm{g})>$ muscle $(215 \mathrm{ng} / \mathrm{g}$ composite, $187 \mathrm{ng} / \mathrm{g}$ individual $)$ $>$ liver $(139 \mathrm{ng} / \mathrm{g})>\operatorname{brain}(63.7 \mathrm{ng} / \mathrm{g})>\operatorname{blood}(12.6 \mathrm{ng} / \mathrm{g})$ (Figure 1). The THg concentrations in the $\mathrm{AJ}(\mathrm{S})$ liver, brain, and blood decreased by $5 \%, 16 \%$, and $22 \%$, respectively, between days 50 and 80 (Figure 1). This was accompanied by a reduction of BAFs for the $\mathrm{AJ}(\mathrm{S})$ liver, brain, and blood (Table 2$)$.

\section{$\mathrm{Hg}$ isotopic compositions in the diets}

The $\delta^{202} \mathrm{Hg}$ and $\Delta^{199} \mathrm{Hg}$ values of $\mathrm{Hg}$ in the tuna were significantly higher compared with the shrimp diet (Figures 2A and $3 \mathrm{~A})$. The average isotopic composition of the tuna diet was $\delta^{202} \mathrm{Hg}=0.55 \pm 0.05 \%$ and $\Delta^{199} \mathrm{Hg}=1.54 \pm 0.01 \%$ 。 $\left(n=3 ; 1\right.$ SD) and the shrimp diet was $\delta^{202} \mathrm{Hg}=-0.48$ $\pm 0.05 \%$ and $\Delta^{199} \mathrm{Hg}=0.32 \pm 0.05 \%$ o $(n=3 ; 1 \mathrm{SD})$. In the tuna, virtually all of the $\mathrm{THg}$ was $\mathrm{MMHg}(>99 \%)$; and in the shrimp, $80 \%$ of the $\mathrm{THg}$ was $\mathrm{MMHg}$.

\section{$\mathrm{Hg}$ isotopic compositions in amberjack}

The AJ muscle, liver, and blood at day 0 displayed a range of $\delta^{202} \mathrm{Hg}$ values from $0.38 \%$ o to $0.59 \%$ and a range of $\Delta^{199} \mathrm{Hg}$ values from $1.63 \%$ o to $3.26 \%$. The brain and kidney could not be measured for $\mathrm{Hg}$ isotopes at day 0 because of the small amount of material. At day 0 , the liver, brain, and kidney contained $41 \%$, $47 \%$, and $39 \%$ of $\mathrm{THg}$ as $\mathrm{MMHg}(\% \mathrm{MMHg})$, respectively. The muscle had $>99 \%$ of $\mathrm{THg}$ as $\mathrm{MMHg}$. We plotted \%MMHg against $\Delta^{199} \mathrm{Hg}$ for the AJ muscle, blood, and liver to test whether the ratio of $\% \mathrm{MMHg}$ to $\mathrm{THg}$ explained the observed
$\Delta^{199} \mathrm{Hg}$ variation in the AJ organs (Figure 4). The $\% \mathrm{MMHg}$ in blood was estimated using values from the literature, which reports approximately $90 \%$ of $\mathrm{THg}$ as $\mathrm{MMHg}$ in the blood of marine fish $[25,26]$. The $\% \mathrm{MMHg}$ and $\Delta{ }^{199} \mathrm{Hg}$ of the AJ muscle, blood, and liver demonstrated a strong correlation $\left(>r^{2}=0.96\right)$. Although our estimate of the isotopic composition of $\mathrm{IHg}$ is based on only a simple linear extrapolation, it is likely that $\mathrm{MMHg}$ and $\mathrm{IHg}$ have different $\mathrm{Hg}$ isotopic compositions and that the extent of $\mathrm{MMHg}$ bioaccumulation in the various organs of the AJ explains the variation of $\Delta^{199} \mathrm{Hg}$ at the start of the experiment.

\section{Tuna treatment}

Because of the difference in the $\mathrm{Hg}$ isotopic composition of $\mathrm{AJ}$ organs at day 0 and the different rate of $\mathrm{Hg}$ isotope reequilibration of the organs to the new food source, 2 mixing lines were plotted: 1) between the tuna diet and the AJ muscle, and 2) between the tuna diet and the AJ blood at day 0 (Figure 2). The mixing lines are described by the equation

$$
{ }^{\mathrm{XXX}} \mathrm{Hg}_{\text {mixture }}={ }^{\mathrm{XXX}} \mathrm{Hg}_{\text {tuna }} f_{\text {tuna }}+{ }^{\mathrm{XXX}} \mathrm{Hg}_{\text {organ } 0} f_{\text {organ } 0}
$$

where ${ }^{\mathrm{XXX}} \mathrm{Hg}$ represents either $\delta^{202} \mathrm{Hg}$ or $\Delta^{199} \mathrm{Hg}$, and $f$ represents the fraction of $\mathrm{THg}$ concentration in either the tuna or the organs of $\mathrm{AJ}(\mathrm{T})$ at day 0 . After $10 \mathrm{~d}$ of consuming the tuna diet, the isotopic compositions of $\mathrm{AJ}(\mathrm{T})$ composite samples of muscle, liver, kidney, brain, and blood shifted to values close to the tuna values. The isotopic composition of $\mathrm{Hg}$ in a single $\mathrm{AJ}(\mathrm{T})$ individual muscle did not shift appreciably after $10 \mathrm{~d}$ (Figure 2). By day 30, the isotopic compositions of $\mathrm{Hg}$ in all organs, including the individual sample of the muscle, had become nearly equal to the isotopic composition of the tuna diet. Only minor changes were observed in both $\delta^{202} \mathrm{Hg}$ and $\Delta^{199} \mathrm{Hg}$ of the $\mathrm{AJ}(\mathrm{T})$ organs (within the analytical uncertainty) at day 50.

\section{Shrimp treatment}

For AJ fed a shrimp diet, 2 mixing lines were plotted: 1) between the shrimp diet and the AJ muscle, and 2) between the shrimp diet and the AJ liver at day 0 (Figure 3). After consuming the shrimp diet for a 10-d period, the isotopic composition of $\mathrm{Hg}$ in the $\mathrm{AJ}(\mathrm{S})$ liver, kidney, and blood shifted toward the isotopic composition of the shrimp diet. After a 30 -d period, we observed a cessation in the changes of $\Delta^{199} \mathrm{Hg}$ and a small shift of $\delta^{202} \mathrm{Hg}$ $(+0.35 \%$ ) away from the mixing line for the liver, kidney, and blood; they did not reach the isotopic composition of the shrimp diet. The brain of $\mathrm{AJ}(\mathrm{S})$, which did not have enough material to be analyzed for days 0 and 10, displayed an isotopic composition similar to that of other organs after $30 \mathrm{~d}$. From day 50 and to the end of the experimental period, the AJ organs showed only minor changes with time in $\delta^{202} \mathrm{Hg}$ and $\Delta^{199} \mathrm{Hg}$ (within the

Table 2. Bioaccumulation factors of amberjack fed shrimp (AJ[S]) or tuna (AJ[T]) at different time points

\begin{tabular}{|c|c|c|c|c|c|c|c|}
\hline & \multicolumn{2}{|c|}{ Day 10} & \multicolumn{2}{|c|}{ Day 30} & \multicolumn{2}{|c|}{ Day 50} & \multirow{2}{*}{$\frac{\text { Day } 80}{\operatorname{AJ}(S)}$} \\
\hline & $\mathrm{AJ}(\mathrm{S})$ & $\mathrm{AJ}(\mathrm{T})$ & $\mathrm{AJ}(\mathrm{S})$ & $\mathrm{AJ}(\mathrm{T})$ & $\mathrm{AJ}(\mathrm{S})$ & $\mathrm{AJ}(\mathrm{T})$ & \\
\hline Liver & 2.49 & 0.18 & 4.02 & 1.00 & 5.84 & 0.88 & 5.52 \\
\hline Kidney & 3.21 & 0.16 & 5.26 & 1.14 & 8.49 & 1.66 & 9.38 \\
\hline Brain & 0.94 & 0.09 & 2.17 & 0.52 & 2.96 & 1.39 & 2.54 \\
\hline Blood & 0.18 & 0.003 & 0.44 & 0.08 & 0.64 & 0.10 & 0.50 \\
\hline
\end{tabular}



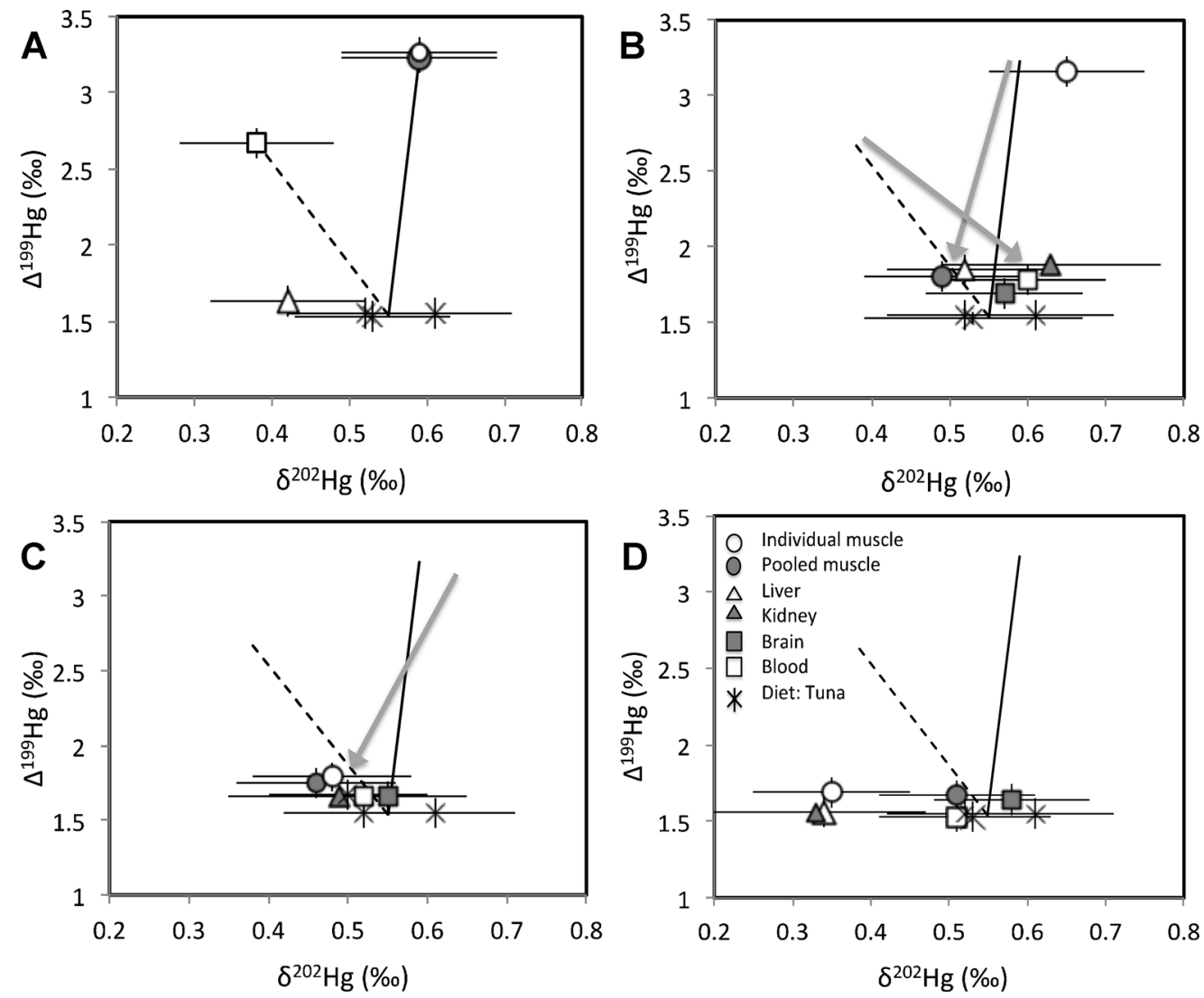

Figure 2. Plot of $\delta^{202} \mathrm{Hg}$ and $\Delta^{199} \mathrm{Hg}$ values of amberjack (AJ) fed a tuna diet at day $0(\mathbf{A})$, day $10(\mathbf{B})$, day $30(\mathbf{C})$, and day 50 (D). The solid line represents the mixing line between the tuna diet and the AJ muscle at day 0 , and the dashed line represents the mixing line between the tuna diet and the AJ blood at day 0 . The arrows represent the shift in the $\mathrm{Hg}$ isotopic composition of each organ from the previous time period. Analytical uncertainty is indicated by the error bar (2 standard deviations).
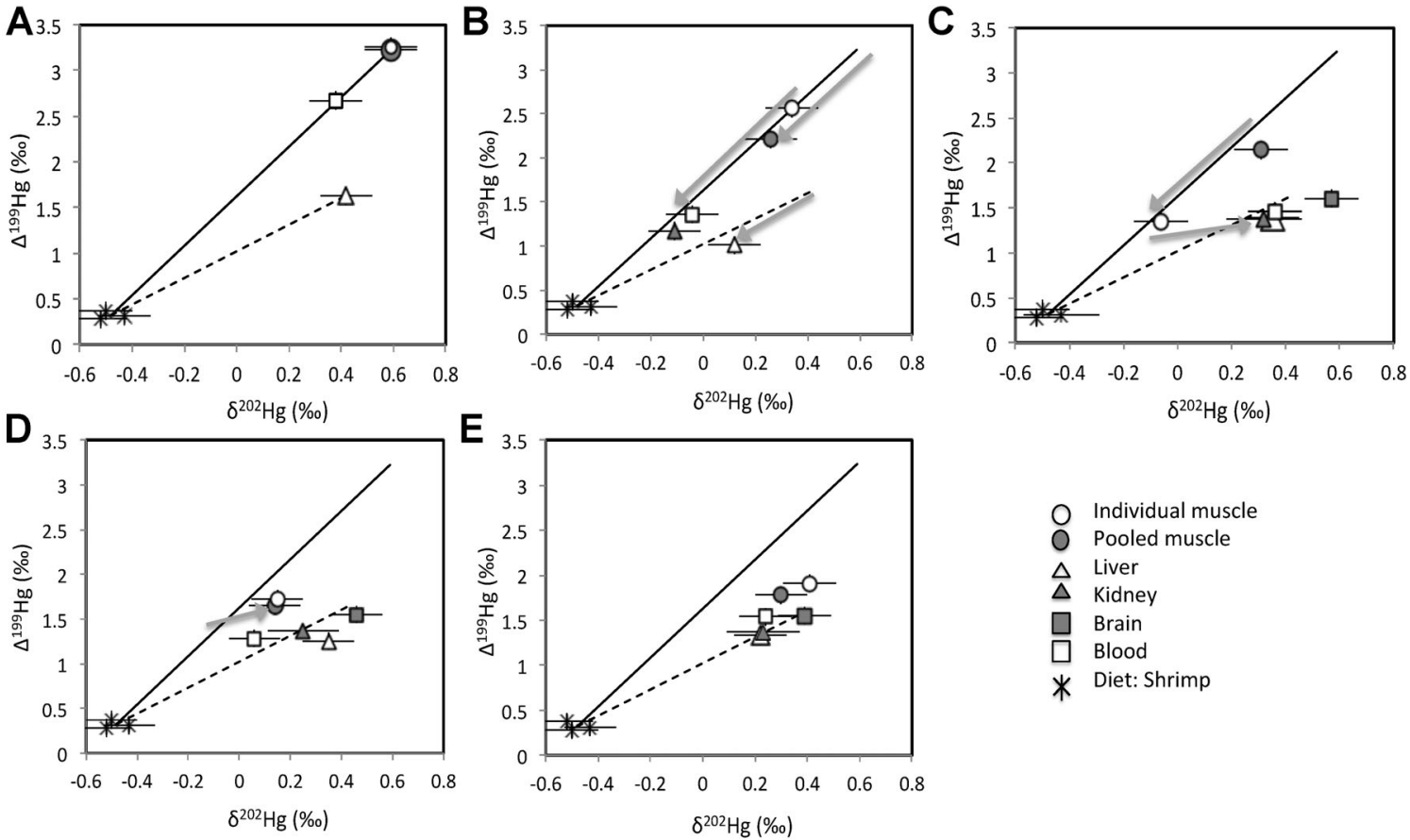

Figure 3. Plot of $\delta^{202} \mathrm{Hg}$ and $\Delta^{199} \mathrm{Hg}$ values of amberjack fed a shrimp diet at day $10(\mathbf{A})$, day $30(\mathbf{B})$, day $50(\mathbf{C})$, day 80 (D), and day 80 (E). The solid line represents the mixing line between the shrimp diet and the AJ muscle at day 0 , and the dashed line represents the mixing line between the shrimp diet and the AJ liver at day 0 . The arrows represent the shift in the $\mathrm{Hg}$ isotopic composition of each organ from the previous time period. Analytical uncertainty is indicated by the error bar (2 standard deviations). 


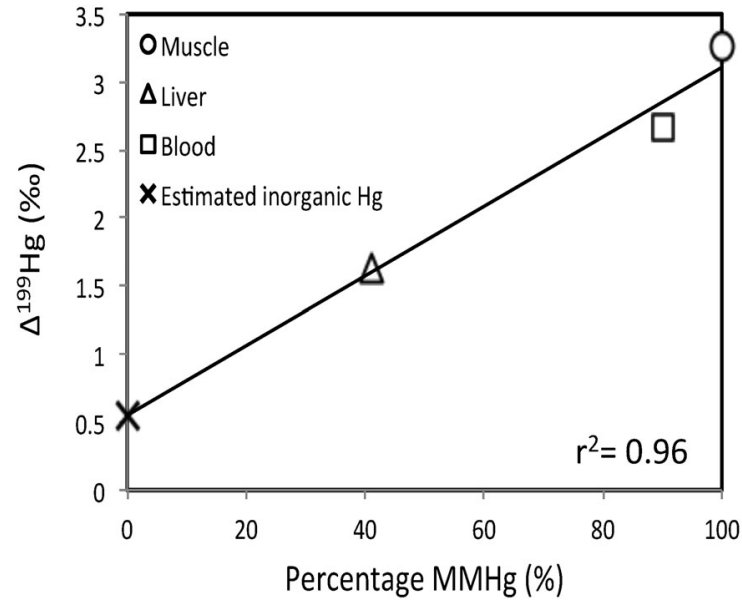

Figure 4. Plot of monomethyl $\mathrm{Hg}$ percentage $(\% \mathrm{MMHg})$ and $\Delta^{199} \mathrm{Hg}$ of the amberjack (AJ) organs at day 0 . The $\Delta^{199} \mathrm{Hg}$ of the inorganic $\mathrm{Hg}$ is extrapolated from the best-fit line of the muscle, liver, and blood of AJ.

analytical uncertainty). The $\mathrm{AJ}(\mathrm{S})$ muscle (composite and individual) demonstrated a delayed response compared with other organs throughout the experimental period, and the isotopic composition of $\mathrm{AJ}(\mathrm{S})$ muscle did not shift away from the mixing line until after day 50 . At the end of the 80 -d period, the liver and kidney contained $38 \%$, and $22 \%$, respectively, of their $\mathrm{THg}$ as $\mathrm{MMHg}$. The muscle and brain contained entirely $\mathrm{MMHg}(>99 \%)$.

\section{Photochemical degradation of $\mathrm{Hg}$ in the Gulf of Mexico}

The experimentally determined $\Delta^{199} \mathrm{Hg} / \Delta^{201} \mathrm{Hg}$ ratio has been used to distinguish the extent of photochemical reduction of $\mathrm{IHg}\left(\Delta^{199} \mathrm{Hg} / \Delta^{201} \mathrm{Hg}=1.00 \pm 0.01\right)$ or photochemical degradation of MMHg $\left(\Delta^{199} \mathrm{Hg} / \Delta^{201} \mathrm{Hg}=1.34 \pm 0.04\right)$ [10]. We calculated the $\Delta^{199} \mathrm{Hg} / \Delta^{201} \mathrm{Hg}$ ratio in $\mathrm{AJ}$ at day 0 prior to the consumption of either the shrimp or the tuna diet and in $\mathrm{AJ}(\mathrm{S})$ and $\mathrm{AJ}(\mathrm{T})$ after the feeding experiments. The $\Delta^{199} \mathrm{Hg} / \Delta^{201} \mathrm{Hg}$ ratio in $\mathrm{AJ}$ at day $0, \mathrm{AJ}(\mathrm{S})$, and $\mathrm{AJ}(\mathrm{T})$ were $1.24 \pm 0.04$ (1 SD), $1.28 \pm 0.11$, and $1.23 \pm 0.02$, respectively. Values for the AJ in the present study are lower than the experimental $\mathrm{MMHg}$ degradation value determined in freshwater experiments using riverine dissolved organic carbon by Bergquist and Blum [10] but are consistent with other values for marine fish (including fish from the Gulf of Mexico) reported previously $\left(\Delta^{199} \mathrm{Hg} /\right.$ $\Delta^{201} \mathrm{Hg}$ of $\left.\sim 1.2\right)[3,5]$. We suggest that the mass-independent fractionation observed in the fish tissues is due to photochemical degradation of $\mathrm{MMHg}$ prior to entry into the Gulf of Mexico marine food web.

\section{DISCUSSION}

\section{Mercury isotopic compositions of the diets and of amberjack before feeding}

The tuna collected from the offshore region display significantly higher $\delta^{202} \mathrm{Hg}$ and $\Delta^{199} \mathrm{Hg}$ compared with the shrimp collected from the coastal region of the Gulf of Mexico. This suggests that the tuna and the shrimp obtain $\mathrm{Hg}$ from different sources or that the $\mathrm{Hg}$ to which they are exposed has been fractionated by different biogeochemical processes. Previous studies that have reported spatial patterns of $\delta^{202} \mathrm{Hg}$ and $\Delta^{199} \mathrm{Hg}$ in fish and sediments suggest that $\mathrm{Hg}$ isotopes can be used to distinguish different $\mathrm{Hg}$ sources [3,5,27]. Senn et al [5], in particular, found higher $\delta^{202} \mathrm{Hg}$ and $\Delta^{199} \mathrm{Hg}$ in offshore fish species compared with coastal fish species in the Gulf of Mexico and attributed this to the uptake of MMHg (by offshore food webs) that was subjected to a higher degree of photochemical degradation than MMHg taken up by coastal food webs. In fact, the isotopic compositions of $\mathrm{Hg}$ associated with coastal fishes $\left(\delta^{202} \mathrm{Hg}=-0.54 \pm 0.32 \%\right.$ and $\Delta^{199} \mathrm{Hg}=0.53 \pm 0.11 \%$ o $)$ and offshore species such as the blackfin tuna $\left(\delta^{202} \mathrm{Hg}=0.41\right.$ $\pm 0.18 \%$ and $\Delta^{199} \mathrm{Hg}=1.75 \pm 0.48 \%$ o ) and juvenile yellowfin tuna $\left(\delta^{202} \mathrm{Hg}=0.54 \pm 0.15 \%\right.$ and $\Delta^{199} \mathrm{Hg}=2.39$ $\pm 0.30 \%$ ) in the Gulf of Mexico [5] are in excellent agreement with the isotopic composition of the shrimp and tuna diets used in our study.

Within the offshore region where both $\mathrm{AJ}$ and tuna were collected, the tuna and the AJ organs at day 0 demonstrated a similar range of $\delta^{202} \mathrm{Hg}$ but considerably different $\Delta^{199} \mathrm{Hg}$, with tuna displaying lower $\Delta^{199} \mathrm{Hg}$ compared with the average $\Delta^{199} \mathrm{Hg}$ of the AJ organs (muscle, liver, blood). Recent studies have shown increasing $\Delta^{199} \mathrm{Hg}$ in organisms occupying decreasing water column depth in both lakes [14] and marine environments [28]. Sherman and Blum [6] also observed a relationship between secchi depth (a measure of light penetration) and $\Delta^{199} \mathrm{Hg}$ values among multiple lakes in Florida such that the fish inhabiting lakes with greater light penetration displayed higher $\Delta^{199} \mathrm{Hg}$ values. Given that juvenile AJ were caught in the surface waters and adult tuna at much greater depths, the differences in the feeding depth and thus the degree of photochemical demethylation in the water column may explain the within-habitat variation of $\Delta^{199} \mathrm{Hg}$ among $\mathrm{AJ}$ and tuna. The similar range of $\delta^{202} \mathrm{Hg}$ in the tuna and the AJ organs is consistent with the offshore region of the Gulf of Mexico receiving the same source of $\mathrm{Hg}$ prior to being subjected to photochemical degradation in different parts of the water column.

Variability was observed in $\Delta^{199} \mathrm{Hg}$ among the AJ organs at day 0 (Figure 4). One explanation for this could be changes in the $\Delta^{199} \mathrm{Hg}$ of food sources prior to capture of $\mathrm{AJ}$, coupled with differences in the residence time of $\mathrm{Hg}$ in different organs. However, a strong correlation between $\% \mathrm{MMHg}$ and $\Delta^{199} \mathrm{Hg}$ of the AJ organs suggests that a difference in $\Delta^{199} \mathrm{Hg}$ between $\mathrm{MMHg}$ and $\mathrm{IHg}$ in food sources [17], and a varying extent of $\mathrm{MMHg}$ versus $\mathrm{IHg}$ bioaccumulation in different organs might also provide an explanation for the $\Delta^{199} \mathrm{Hg}$ variability in the specific organs of the AJ.

\section{Tuna treatment}

When AJ consumed the tuna diet, which had 35 times higher $\mathrm{THg}$ concentration compared with the initial AJ muscle and composed mainly of $\mathrm{MMHg}$, there was a dramatic shift in the $\mathrm{Hg}$ isotopic composition of the $\mathrm{AJ}(\mathrm{T})$ organs toward the tuna value within $10 \mathrm{~d}$ of the feeding experiment. The isotopic composition of all $\mathrm{AJ}(\mathrm{T})$ organs nearly equaled the isotopic composition of the tuna diet within $30 \mathrm{~d}$ of consuming the tuna. A previous study in which food pellets spiked with $\mathrm{MMHg}$ were fed to juvenile yellow perch and bloater $(86 \% \mathrm{MMHg})$ were fed to lake trout also demonstrated direct transfer of the $\mathrm{Hg}$ isotopic composition of the food to fish [17] and attributed this to the rapid assimilation and trophic transfer of MMHg. Similarly, in the present study, the uptake of a naturally high-MMHg tuna diet, which led to the rapid increase in $\mathrm{THg}$ concentrations in the $\mathrm{AJ}(\mathrm{T})$ organs, appears to have caused rapid re-equilibration of the $\mathrm{Hg}$ isotopic composition of the internal organs to the new food source.

It is interesting to note the similarity in the patterns of the $\mathrm{Hg}$ isotope distribution among organs that we observed to that found in previous studies. Pharmacokinetic studies have documented 
rapid transfer of $\mathrm{MMHg}$ to the visceral organs (liver, kidney, spleen, gill) via blood and a much slower turnover of $\mathrm{Hg}$ in the muscle $[25,29,30]$, which is what we observed in our feeding experiments (Figure 2). A number of radiotracer studies that exposed adult freshwater and saltwater fish to experimental diets spiked with $\mathrm{MMHg}$ suggested that it requires approximately $30 \mathrm{~d}$ for $\mathrm{MMHg}$ to be detected in fish muscle [29,30], which is consistent with the findings of the present study. Thus, with the demonstrated efficient assimilation of high-MMHg diets, we can expect to observe an absence of $\mathrm{Hg}$ isotope fractionation in major fish organs on internal distribution and trophic transfer of a high$\mathrm{MMHg}$ diet.

\section{Shrimp treatment}

Amberjack fed with shrimp, which had a THg concentration 105 times lower than the tuna food source, displayed substantially different patterns of internal distribution of $\mathrm{Hg}$ isotopes. During the first $10 \mathrm{~d}$ of the feeding experiment, increases in the $\mathrm{THg}$ concentrations of the $\mathrm{AJ}(\mathrm{S})$ organs were accompanied by mixing of the $\mathrm{Hg}$ isotopic compositions between the values of the $\mathrm{AJ}(\mathrm{S})$ organs and the shrimp diet, indicating that bioaccumulation of shrimp $\mathrm{Hg}$ was taking place without isotope fractionation. After the 30-d period, however, there was a cessation in further shifts in $\Delta^{199} \mathrm{Hg}$ toward the shrimp value and a small shift in $\delta^{202} \mathrm{Hg}$ by $\sim 0.35 \%$ in the $\mathrm{AJ}(\mathrm{S})$ organs away from the mixing line. We attribute the cessation of changes in $\Delta^{199} \mathrm{Hg}$ to the reduction in the feeding rate of $\mathrm{AJ}(\mathrm{S})$ and the small shift of $\delta^{202} \mathrm{Hg}$ to a small internal fractionation of $\delta^{202} \mathrm{Hg}$.

As discussed in the previous section, $\Delta^{199} \mathrm{Hg}$ is the best indicator for monitoring the trophic transfer of $\mathrm{MMHg}$ and mixing of 2 isotopically distinct reservoirs of $\mathrm{Hg}$, because internal metabolic processes are unlikely to cause any fractionation of $\Delta^{199} \mathrm{Hg}[9,17]$. The fact that $\Delta^{199} \mathrm{Hg}$ of the AJ(S) organs ceased to mix with the shrimp diet and displayed only minor changes after the 30-d period suggests that the $\mathrm{Hg}$ associated with the shrimp was no longer effectively being transferred to the $\mathrm{AJ}(\mathrm{S})$. We suggest that this is most likely caused by the stressrelated feeding inhibition behavior among $\mathrm{AJ}(\mathrm{S})$. After $30 \mathrm{~d}$ of the feeding experiment, $\mathrm{AJ}(\mathrm{S})$ began to refuse the shrimp diet and reached mortality close to the end of the experiment. Thus, given the low $\mathrm{THg}$ concentration in the shrimp diet and decrease in the feeding rate of $\mathrm{AJ}(\mathrm{S})$, the bioaccumulation of shrimp $\mathrm{Hg}$ might have been too small to cause a measureable additional shift in the $\Delta^{199} \mathrm{Hg}$ of $\mathrm{AJ}(\mathrm{S})$ organs.

It is possible that, with different isotopic compositions of $\mathrm{IHg}$ and $\mathrm{MMHg}$, a shift in the differential uptake and excretion of these $2 \mathrm{Hg}$ species could lead to the observed $\delta^{202} \mathrm{Hg}$ shift in the $\mathrm{AJ}(\mathrm{S})$ organs. For such a large shift to occur via the uptake or excretion of $\mathrm{IHg}$, however, the shrimp diet would need to contain a large proportion of $\mathrm{THg}$ as $\mathrm{IHg}$, which is not what we observed. Moreover, while we can assume that the isotopic composition of the $\mathrm{AJ}(\mathrm{S})$ muscle at day 80 reflects the isotopic composition of bioaccumulated $\mathrm{MMHg}$ ( $>99 \% \mathrm{THg}$ as $\mathrm{MMHg}$ ), this isotopic composition cannot be used to estimate the isotopic composition of $\mathrm{IHg}$ in the shrimp diet given the potential fractionation of $\delta^{202} \mathrm{Hg}$ during internal metabolism and uptake [8,9]. Kritee et al. [9] observed a kinetic fractionation of $\delta^{202} \mathrm{Hg}$, but not in $\Delta^{199} \mathrm{Hg}$, during the microbial demethylation of $\mathrm{MMHg}$ such that the reactant $(\mathrm{MMHg})$ became enriched in heavier $\delta^{202} \mathrm{Hg}$ compared with the product ( $\mathrm{IHg}$ ). Several studies have shown evidence for microbial transformation of $\mathrm{Hg}$ species in the intestines of fish [31] and in aquatic sediments [32]. Thus, a possible scenario is that there is microbial demethylation of $\mathrm{MMHg}$ in the $\mathrm{AJ}(\mathrm{S})$ intestines, followed by preferential trophic transfer of the remaining (higher $\delta^{202} \mathrm{Hg}$ ) $\mathrm{MMHg}$ to the internal organs of $\mathrm{AJ}(\mathrm{S})$, with excretion of the low $\delta^{202} \mathrm{Hg} \mathrm{IHg}$ product from the body. This somewhat speculative scenario will require further testing.

With reduction in the feeding rate, it is possible that remobilization of fat and protein from liver and muscle tissues during starvation [33] facilitated the excretion of $\mathrm{MMHg}$, leading to the small fractionation of $\delta^{202} \mathrm{Hg}$ in the $\mathrm{AJ}(\mathrm{S})$ organs. Although we do not have physiological evidence to support remobilization from the $\mathrm{AJ}(\mathrm{S})$ organs, decrease in the $\mathrm{THg}$ concentrations and BAFs in the liver, brain, and blood after day 50 indicates that the $\mathrm{Hg}$ bioaccumulation began to slow and that excretion might have been enhanced in $\mathrm{AJ}(\mathrm{S})$. In fact, the reduction in $\mathrm{THg}$ concentrations in the visceral organs followed by the redistribution of $\mathrm{Hg}$ to the storage organs (muscle and kidney) has been observed repeatedly in $\mathrm{Hg}$ elimination studies in fish [29,34], which is consistent with what we observed in the $\mathrm{AJ}(\mathrm{S})$ organs with time. If this is the case, we expect that $\mathrm{MMHg}$ with lower $\delta^{202} \mathrm{Hg}$, which is generally more reactive [9], would be preferentially excreted while the heavier $\mathrm{Hg}$ isotopes remain in the organs, thus leading to the enrichment of $\delta^{202} \mathrm{Hg}$ in the AJ (S) organs during excretion. As a side note, Laffont et al. [35] reported an enrichment of $\delta^{202} \mathrm{Hg}$ by $2 \%$ in human hair compared with a dietary source of $\mathrm{MMHg}$ from fish, which implies that internal processes in mammals can in some instances lead to the fractionation of $\delta^{202} \mathrm{Hg}$.

In summary, it appears that the consumption of a low- $\mathrm{Hg}$ shrimp diet and changes in the physiological state allowed the detection of incomplete turnover and mixing of $\mathrm{MMHg}$ in the $\mathrm{AJ}$ (S) organs and a small internal fractionation of $\delta^{202} \mathrm{Hg}$. This is in contrast to the present experiments with a high- $\mathrm{Hg}$ tuna diet and a previous study of freshwater fish [17], which reported an absence of $\delta^{202} \mathrm{Hg}$ and $\Delta^{199} \mathrm{Hg}$ fractionation during trophic transfer and the complete re-equilibration of the $\mathrm{AJ}(\mathrm{T})$ organs on exposure to a high-MMHg diet. It is important to emphasize that the major differences between the experiments is the $\mathrm{THg}$ concentration in the diet and the feeding rate of the fish. Thus, the present study suggests that although the active consumption of a high-MMHg diet results in rapid turnover in all organs of fish to the isotopic composition of a new food source through efficient $\mathrm{MMHg}$ assimilation, reduction in $\mathrm{Hg}$ bioaccumulation and feeding rate caused by changes in the physiological state of fish can lead to incomplete shift of $\mathrm{Hg}$ isotopes to a new food source.

\section{Application of $\mathrm{Hg}$ isotopes in natural marine systems}

The present study has explored the behavior of stable $\mathrm{Hg}$ isotopes during the trophic transfer and internal distribution of $\mathrm{Hg}$ in marine fish. Previous studies using radiotracers offered quantitative estimates of the extent of trophic transfer and assimilation of dietary $\mathrm{Hg}$ in various species of fish [36,37]. The application of stable $\mathrm{Hg}$ isotopes provides unique insight into the sources of $\mathrm{Hg}$ to fish and the processes of trophic transfer of $\mathrm{Hg}$ in fish consuming natural diets. The ability to identify sources and monitor the process of $\mathrm{Hg}$ trophic transfer has the potential to aid in understanding of ecologically relevant $\mathrm{Hg}$ biogeochemical processes in natural marine ecosystems. For instance, transport of coastal MMHg to the open ocean via bioadvection and horizontal trophic transfer has been suggested to play an important role in providing $\mathrm{MMHg}$ to open ocean food webs [38]. However, distinguishing the relative importance of coastal versus offshore MMHg sources to marine food webs has been limited with previous techniques. Given that the $\mathrm{Hg}$ source can be monitored with stable $\mathrm{Hg}$ isotopes in fish tissues, we can now 
begin to distinguish the relative importance of $\mathrm{Hg}$ sources in marine food webs.

The finding that the physiological state of fish and the $\mathrm{THg}$ concentration in their diet can influence the $\mathrm{Hg}$ isotopic equilibration of various organs and tissues indicates that these parameters must be taken into consideration when using $\mathrm{Hg}$ isotopes in fish to identify sources and biogeochemical processes in natural marine systems. For instance, whereas species feeding at high trophic levels and consuming high-MMHg diets are expected to reflect the dominant $\mathrm{MMHg}$ source of their marine environment, the identification of $\mathrm{Hg}$ sources in species that do not actively ingest food during certain seasons or life cycles may be difficult because of the slow transition of $\Delta^{199} \mathrm{Hg}$ from a new diet and the potential fractionation of $\delta^{202} \mathrm{Hg}$. Even if the fish depend exclusively on high-MMHg diets, the fact that various ecological factors such as fish size, trophic position, habitat, and food sources can influence the $\mathrm{THg}$ concentrations in aquatic organisms $[39,40]$ indicates that prey-predator relationships must be well constrained before selecting a biosentinel fish species to monitor $\mathrm{Hg}$ pollution. Moreover, the utilization of $\mathrm{Hg}$ isotopes may be more applicable to sites that are severely affected by a single point source, as demonstrated in studies using $\mathrm{Hg}$ isotopes in sediments [27]. More research is required to understand how internal processes such as demethylation and excretion lead to the small observed fractionation of $\delta^{202} \mathrm{Hg}$. Nevertheless, we suggest that using stable $\mathrm{Hg}$ isotope techniques to trace $\mathrm{Hg}$ sources and trophic transfer in marine food webs has the potential to become a regular and important part of biomonitoring and ecological risk assessment.

Acknowledgment-We thank M. Johnson for operation of the MC-ICP-MS C. Hammerschimdt at Wright State University, Dayton, Ohio, USA; S. Balogh and Y. Nollet at Metropolitan Council Environmental Services, St Paul, Minnesota, USA; and M.T.K. Tsui at the University of Michigan, Ann Arbor, Michigan, USA, provided MMHg analyses.

\section{REFERENCES}

1. Mergler D, Anderson HA, Chan LHM, Mahaffey KR, Murray M, Sakamoto M, Stern AH. 2007. Methylmercury exposure and health effects in humans: A worldwide concern. Ambio 36:3-11.

2. Sunderland EM. 2007. Mercury exposure from domestic and imported estuarine and marine fish in the U.S. seafood market. Environ Health Perspect 115:235-242.

3. Gehrke GE, Blum JD, Slotton DG, Greenfield BK. 2011. Mercury isotope link mercury in San Francisco Bay forage fish to surface sediments. Environ Sci Technol 45:1264-1270.

4. Point D, Sonke JE, Day RD, Roseneau DG, Hobson KA, Vander Pol SS, Moors AJ, Pugh RS, Donard OFX, Becker PR. 2011. Methylmercury photodegradation influenced by sea-ice cover in Arctic marine ecosystems. Nature Geosci 4:188-194.

5. Senn DB, Chesney EJ, Blum JD, Bank MS, Maage A, Shine JP. 2010. Stable isotope (N, C, Hg) study of methylmercury sources and trophic transfer in the northern Gulf of Mexico. Environ Sci Technol 44:16301637

6. Sherman LS, Blum JD. 2012. Mercury stable isotopes in sediments and largemouth bass from Florida lakes, USA. Sci Total Environ 448:163175 .

7. Blum JD, Bergquist BA. 2007. Reporting of variations in the natural isotopic composition of mercury. Anal Bioanal Chem 388:353-359.

8. Rodriguez-Gonzalez P, Epov VN, Bridou R, Tessier E, Guyoneud R, Monperrus M, Amouroux D. 2009. Species-specific stable isotope fractionation of mercury during $\mathrm{Hg}$ (II) methylation by an anaerobic bacteria (Desulfobulbus propionicus) under dark conditions. Envrion Sci Technol 43:9183-9188.

9. Kritee K, Barkay T, Blum JD. 2009. Mass dependent stable isotope fractionation of mercury during mer mediated microbial degradation of monomethylmercury. Geochim Cosmochim Acta 73:1285-1296.

10. Bergquist BA, Blum JD. 2007. Mass-dependent and -independent fractionation of $\mathrm{Hg}$ isotopes by photoreduction in aquatic systems. Science 318:417-420.
11. Schauble EA. 2007. Role of nuclear volume in driving equilibrium stable isotope fractionation of mercury, thallium, and other very heavy elements. Geochim Cosmochim Acta 71:2170-2189.

12. Buchachenko AL, Ivanov VL, Roznyatovskii VA, Vorob'ev AK, Ustynyuk YA. 2008. Inversion of the sign of the magnetic isotope effect of mercury in photolysis of substituted dibenzylmercury. Dokl Phys Chem 420:85-87.

13. Zheng W, Hintelmann H. 2009. Mercury isotope fractionation during photoreduction in natural water is controlled by its $\mathrm{Hg} / \mathrm{DOC}$ ratio. Geochim Cosmochim Acta 27:6704-6715.

14. Gantner N, Hintelmann H, Zheng W, Muir DC. 2009. Variations in stable isotope fractionation of $\mathrm{Hg}$ in food webs of Arctic lakes. Environ Sci Technol 43:9148-9154.

15. Chen JB, Hintelmann H, Feng XB, Dimock B. 2013. Unusual fractionation of both odd and even mercury isotopes in precipitation from Peterborough, ON, Canada. Geochim Cosmochim Acta 90:33-46.

16. Gratz LE, Keeler GJ, Blum JD, Sherman LS. 2010. Isotopic composition and fractionation of mercury in Great Lakes precipitation and ambient air. Environ Sci Technol 44:7764-7770.

17. Kwon SY, Blum JD, Carvan MJ, Basu N, Head JA, Madenjian CP, David SR. 2012. Absence of fractionation of mercury isotopes during trophic transfer of methylmercury to freshwater fish in captivity. Environ Sci Technol 46:7527-7534.

18. Perrot V, Pastukhov MV, Epov VN, Husted S, Donard OFX, Amouroux D. 2012. Higher mass-independent isotope fractionation of methylmercury in the pelagic food web of Lake Baikal (Russia). Environ $\mathrm{Sci}$ Technol 46:5902-5911.

19. Demers JD, Blum JD, Zak DR. 2013. Mercury isotopes in a forested ecosystem: Implications for air-surface exchange dynamics and the global mercury cycle. Global Biogeochem Cy 27:1-17.

20. Estrade N, Carignan J, Donard OFX. 2010. Isotope tracing of atmospheric mercury sources in an urban area of northeastern France. Environ Sci Technol 44:6062-6067.

21. Yin R, Feng X, Meng B. 2013. Stable mercury isotope variation in rice plants (Oryza sativa L.) from the Wanshan mercury mining district, SW China. Environ Sci Technol 47:2238-2245.

22. Badalamenti F, D’Anna G, Lopiano L, Scilipoti D, Mazzola A. 1995 Feeding habits of young-of-the-year greater amberjack Seriola dumerili (Risso, 1810) along the N/W Sicilian coast. Sci Mar 59:317-323.

23. Hammerschmidt CR, Fitzgerald WF. 2006. Methylmercury in freshwater fish linked to atmospheric mercury deposition. Environ Sci Technol 40:7764-7770.

24. Zook EG, Powell JJ, Hackley BM, Emerson JA, Brooker JR, Knobl GM Jr. 1976. National marine fisheries service preliminary survey of selected seafoods for mercury, lead, cadmium, chromium, and arsenic content. $J$ Agric Food Chem 24:47-53.

25. de Oliveira Ribeiro CA, Rouleau C, Pelletier E, Audet C, Tjalve H. 1999. Distribution kinetics of dietary methylmercury in the Arctic charr (Salvelinus alpinus). Environ Sci Technol 33:902-907.

26. Riisgard HU, Hansen S. 1990. Biomagnification of mercury in a marine grazing food-chain: Algal cells Phaedodactylum trichornutum, mussels Mytilus edulis and flounder Platichthys flesus studied by means of a stepwise reduction-CVAA method. Mar Ecol Prog Ser 62:259-270.

27. Foucher D, Ogrinc N, Hintelmann H. 2009. Tracing mercury contamination from the Idrija mining region (Slovenia) to the Gulf of Trieste using Hg isotope ratio measurements. Environ Sci Technol 43:33-39.

28. Blum JD, Popp BN, Johnson MW, Drazen JC, Choy A. 2012. Mercury isotope constraints on depth of methylation and degree of photodegradation of methylmercury in the Central Pacific Ocean. Abstracts, 2012 Fall Meeting, American Geophysical Union, December, San Francisco, CA, USA, December 3-7.

29. Lerner JJ, Mason RP. 2004. Methylmercury uptake and distribution kinetics in sheepshead minnows, Cyprinodon variegates, after exposure to $\mathrm{CH}_{3} \mathrm{Hg}$-spiked food. Environ Toxicol Chem 23:2138-2146.

30. McCloskey JT, Schultz IR, Newman MC. 1998. Estimating the ora bioavailbility of methylmercury to channel catfish (Ictalurus punctatus). Environ Sci Technol 17:1524-1529.

31. Rudd JW, Furutani A, Turner MA. 1980. Mercury methylation by fish intestinal contents. Appl Environ Microbiol 40:777-782.

32. Pak KR, Bartha R. 1998. Mercury methylmation and demethyation in anoxic lake sediments and by strictly anaerobic bacteria. Appl Environ Microbiol 64:1013-1017.

33. Tseng YC, Hwang PP. 2008. Some insights into energy metabolism for osmoregulation in fish. Comp Biochem Phys C 148:419-429.

34. Van Walleghen JLA, Blanchfield PJ, Hintelmann H. 2007. Elimination of mercury by yellow perch in the wild. Environ Sci Technol 41:5895-5901.

35. Laffont L, Sonke JE, Maurice L, Monrroy SL, Chincheros J, Amouroux D, Behra P. 2011. Hg speciation and stable isotope signature in human 
hair as a tracer for dietary and occupational exposure to mercury. Environ Sci Technol 45:9910-9916.

36. Pickhardt PC, Stepanova M, Fisher NS. 2006. Contrasting uptake routes and tissue distribution of inorganic and methylmercury in mosquitofish (Gambusia affinis) and redear sunfish (Lepomis microlophus). Environ Toxicol Chem 25:2132-2142.

37. Wang WX, Wong RSK. 2003. Bioaccumulation kinetics and exposure pathways of inorganic mercury and methylmercury in a marine fish, the sweetlips Plectorhinchus gibbosus. Mar Ecol Prog Seri 261:257-268.
38. Hammerschmidt CR, Fitzgerald WF. 2006. Methylmercury cycling in sediments on the continental shelf of southern New England. Geochim Cosmochim Acta 70:918-930.

39. Chumchal MM, Manbright KD. 2009. Ecological factors regulating mercury contamination of fish from Caddo Lake, Texas, USA. Environ Toxicol Chem 28:962-972.

40. Swanson HK, Kidd KA. 2010. Mercury concentrations in arctic food fishes reflect the presence of anadromous arctic charr (Salvelinus alpinus), species, and life history. Environ Sci Technol 44:3286-3292. 